Article

\title{
The Contribution of Different Restored Habitats to Fish Diversity and Population Development in a Highly Modified River: A Case Study from the River Günz
}

\author{
Joachim Pander and Juergen Geist * \\ Aquatic Systems Biology Unit, Department of Ecology and Ecosystem Management, Technical University of \\ Munich, Mühlenweg 18-22, D-85350 Freising, Germany; joachim.pander@tum.de \\ * Correspondence: geist@wzw.tum.de; Tel.: +49-8161-713767
}

Received: 10 August 2018; Accepted: 3 September 2018; Published: 6 September 2018

check for updates

\begin{abstract}
Despite of structural deficits, highly modified water bodies (HMWB) contain remnant populations of endangered fish that have high conservation value. Restoration in HMWBs underlies different principles when compared to natural rivers because of impaired river dynamic processes. The objective herein was to assess the contribution of restored habitats of the River Günz, Germany to fish diversity and restoration success of target species. All habitat restoration types, including bank habitats, fast flowing habitats with gravel, structured shallow water zones, nature like fish passes, and a former river course below a spillway were assessed. None of them comprised the full set of 27 fish species or size classes, indicating that the diversity and interlinkage of the restored habitats is most crucial to sustainable fish populations and high biodiversity. When considering the rheophilic target species Chondrostoma nasus and Barbus barbus, only fish passes and the former river course with their high flow current contributed much to their population development, particularly to young specimens $<20 \mathrm{~cm}$. The results of this study indicate that measures inside the main channel are unlikely to mitigate deficiencies in HMWBs concerning specialized riverine fish. Instead, interlinkage of a diversity of restoration measures and investment of resources for restoration in HMWBs into nature-like fish passes or former river courses below spillways with dynamically managed discharges seem most useful.
\end{abstract}

Keywords: fish habitat; heavily modified waterbody; river restoration; spillway; channelization; fish pass; biodiversity conservation; hydropower

\section{Introduction}

Many European rivers have faced fundamental structural changes throughout the last centuries and they are now heavily fragmented and channelized. This often resulted in their recent classification as heavily modified water bodies (HMWB) in the European Water Framework Directive (WFD) assessment [1] with $37 \%$ of all German rivers classified as HMWBs. However, HMWB are known to be important fish habitats, since they very often harbor remnant populations of highly endangered fishes [2-4]. Consequently, HMWB should also be considered in conservation management of highly protected fish species, as well as in the general conservation of fish diversity $[3,4]$. The formulated goals of the WFD to reach the "good ecological potential" in these waters, at the latest by 2027 (https://www.lfu.bayern.de/wasser/wrrl/index.htm), create the urgent need to restore the degraded riverine habitats [5]. In addition to biological conservation aspects, restoration in HMWBs must also take into account flood protection, hydropower generation, and the limited land availability adjacent to the rivers $[3,6]$. Therefore, in HMWBs, habitat restoration mostly addresses measures inside of 
the channel course (instream measures), such as creating shallow riverbanks [4,7] or introducing spawning substrate [8]. It has been shown that such measures can be important restoration actions, since bank habitats create the interlinkage between the river and its surrounding terrestrial habitats, thus improving lateral connectivity $[9,10]$. For instance, slow flowing and shallow habitats, which are mostly located near river banks are key habitats in the life cycle of Chondrostoma nasus L. (common nase) and Barbus barbus L. (common barbel) [11-16] and the restoration of such habitats was described to result in improved population development, as well as greater fish diversity at these sites [10,17]. Such positive effects of restored bank habitats [18] are mostly based on increased habitat heterogeneity at the microhabitat scale [19] that are caused by a variety of light conditions at river banks due to riparian shading, substrate, depth and current variability (reviewed in [10]) and the resulting complex habitat structures comprising also highly interlinked food-web properties [10]. In addition to modifications inside the river channel, more and more focus is given on creating fish habitats outside of the main channel. Some of these measures are even thought to serve multiple purposes. For example, nature like fish-passes are often built if the river is fragmented by low-head obstacles often in conjunction with hydropower use [20]. Their primary purpose is mostly to restore fish passage and migration, but due to their hydraulic gradients, they can also comprise valuable key habitats for fish, such as spawning grounds, which are often limiting in the main river due to its channelization and homogenization of water depth and current speed [21]. Another restoration option is the improvement of fish habitats in former river courses below spillways by inducing varying environmental flows [22,23] in combination with structural measures, such as large boulders and gravel introductions. Often, these old river courses comprise the only remaining possibility for river dynamic process [24] in the HMWB that are crucial to renew functional habitats for critical life stages, such as spawning, juvenile life stages, and feeding habitats for rheophilic specialists.

Herein, the effects of five different restoration strategies on fish diversity and population development in the highly modified river Günz (Figure 1) were investigated and tested for their contribution to fish community structures. Focus was placed on the fish community structure of the target species $C$. nasus and B. barbus, since healthy populations of these rheophilic specialists were the main goal of the restoration. Specifically, we hypothesised that responses of the fish population to the restoration measures are not attributable to single restored habitat types, such as restoring bank habitats or creating shallow water zones for juveniles (instream measures of the main channel) or measures outside the main channel, such as nature like fish passes or the restoration of the former water course below the spillway (which comprise a more integrated restoration approach also addressing juvenile habitats and spawning grounds), but that instead a combination of different types of measures results in greater fish species richness and diversity. Furthermore, we hypothesised that species that are highly specialised (e.g., C. nasus, B. barbus) differ in their response to the restoration in comparison to more generalist species (e.g., Squalius cephalus L., common chub) due to their more complex life history strategies and habitat requirements. The study river assessed herein represents an ideal model stream, since its river course was heavily changed over centuries (Figure 1) with a serious loss of river length (more than 55\%) and a dramatic decline of the two target species of fish conservation over the last decades. After restoration, all of the assessed habitats are highly interlinked (Figures 2 and 3) and therefore allow for a comprehensive comparison of the different measures in different parts of the system. Additionally, restoration effects of bank habitats of the main channel and substratum restoration in the former river course downstream the spillway were already comprehensively assessed [3,4,18,25]. 


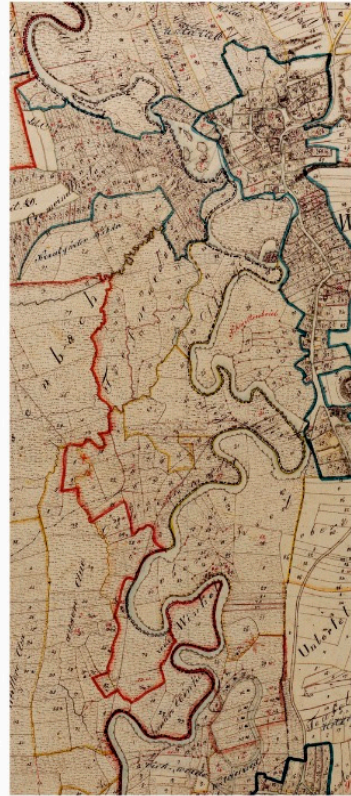

general parcelling map first record 1823

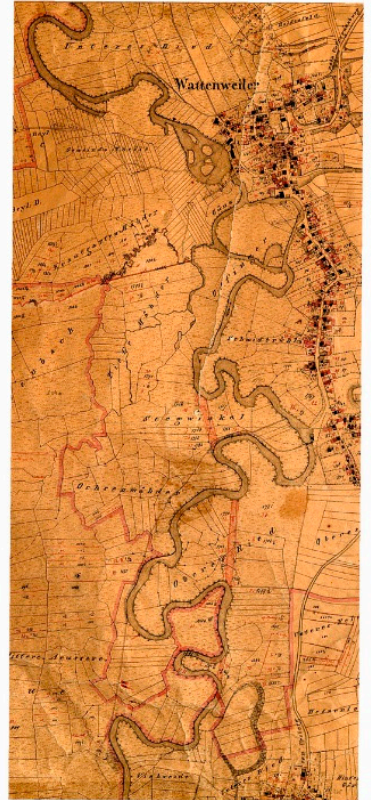

general parcelling map 1870

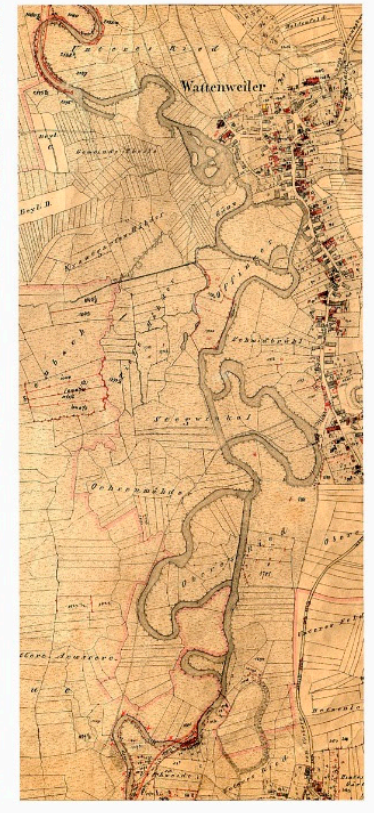

general parcelling map 1906

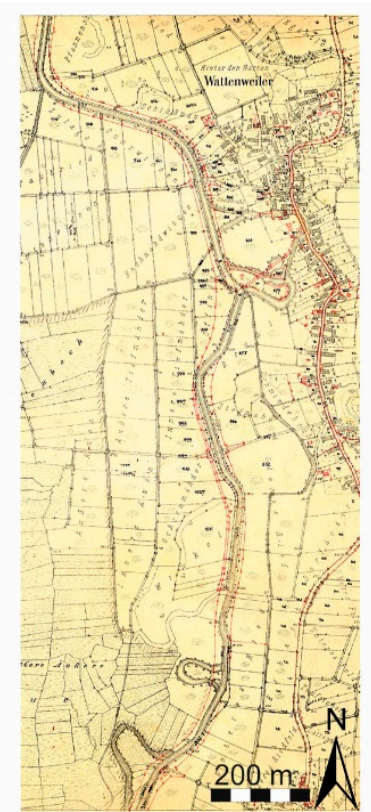

general parcelling map 1965 before implementing the PP Wattenweiler

Figure 1. Visualisation of the changes in river morphology of the Günz river between 1823 and 1965 in the general parcelling map. Red lines in the plot of 1965 indicate the final and present condition of the channelization of the study area that was completed with the implementation of the power plant (PP) Wattenweiler in 1965.

\section{Materials and Methods}

\subsection{Study Area}

The river Günz is located in the south of Germany (Bavaria), in the drainage system of the river Danube (Figure 2). The study river is a right hand tributary of the Danube and discharges into it in the town of Günzburg (coordinates: $48^{\circ} 27^{\prime} 16^{\prime \prime} \mathrm{N}, 10^{\circ} 16^{\prime} 28^{\prime \prime} \mathrm{E}$ ). The river length is $55 \mathrm{~km}$ and its catchment area is about $710 \mathrm{~km}^{2}$. A map of the study river with its geolocation is shown in Figure 2 and is also presented in Pander and Geist [3,4]. Since 1823, the river course corrections and channelization of the Günz have been recorded in general parceling maps and are presented in Figure 1. The structural modifications of the Günz are mainly attributed to flood protection, gaining farmland and hydropower generation. The construction of the recent river course with the present dams and weirs was finished in 1965. Until that time, the river had already lost more than $55 \%$ (approximately $57 \mathrm{~km}$ river course) of its former river length. Today, the study river is blocked with 102 weirs and five reservoirs. The study area is located between the city of Ellzee (location of the hydropower plant Ellzee, coordinates: $48^{\circ} 19^{\prime} 57^{\prime \prime} \mathrm{N}$, $10^{\circ} 19^{\prime} 09^{\prime \prime} \mathrm{E}$ ) and the city of Deisenhausen (location of the weir near Deisenhausen where the "old Günz is diverted from the main channel, coordinates: $48^{\circ} 15^{\prime} 55^{\prime \prime} \mathrm{N}, 10^{\circ} 19^{\prime} 14^{\prime \prime} \mathrm{E}$ ). The study area extends over $8.5 \mathrm{~km}$ river course, which currently only has a small hydraulic gradient of $0.0161 \%$ in the main channel. The annual discharge is driven by snow-melt induced high flows that typically occur during spring season and storm-induced summer floods. The mean annual discharge of the Günz (measured at the water gauge near the town of Waldstetten, $48^{\circ} 21^{\prime} 09^{\prime \prime} \mathrm{N}, 10^{\circ} 18^{\prime} 08^{\prime \prime} \mathrm{E}$ ) is about $8.35 \mathrm{~m}^{3} \cdot \mathrm{s}^{-1}$ and can range between $3 \mathrm{~m}^{3} \cdot \mathrm{s}^{-1}$ to $130 \mathrm{~m}^{3} \cdot \mathrm{s}^{-1}$. The watershed area of this specific water gauge is about $596 \mathrm{~km}^{2}$. To mitigate the ecological deficits concerning the fish population in the context of the WFD, the operating company of the hydropower plants the Bayerische Elektizitätswerke GmbH (BEW) carried out intensive fish habitat restoration measures according to national standards. The restoration work was carried out between 2007 and 2012, comprising the creation of bank habitats, instream habitats, fish-passes, and the restoration of the former river course the "old Günz" that is nowadays 
used as a spillway (Figure 2). The river Günz still holds a remnant population of the endangered target species $C$. nasus and B. barbus. Both of the species have complex life cycles comprising a chronology of different habitat uses. The species spawn at sites with high current speed and low water depth over coarse gravel [26]. The eggs and larvae depend on an oxygen-rich interstitial zone with high water exchange rates and the emerged larvae are passively drifted downstream into shallow water zones near the riverbank where they further develop into juveniles [27]. These fish can use different habitats from reconnected oxbows (C. nasus) to shallow riffle sequences that comprise large boulders or stones to hide (B. barbus). In their early life stages, both of the species are highly dependent on shelter with low current velocities during flood events and in their adult phase, they need deep pools for overwintering. C. nasus is classified as herbivorous and feeds mainly on algae growing on the substrate of the river bottom, whilst B. barbus primarily feeds on macroinvertebrates [26].

\subsection{Study Design}

To assess the different restored habitats of the Günz system (Figures 2 and 3) for their individual contributions to fish species richness, diversity, and restoration success concerning population development of target species in conservation, all the available restored habitat types of the system were assessed. These comprised four types of bank habitats (with each nine replicates as described in Pander and Geist [3,4], Figure 3), fast-flowing instream habitats with gravel (three $30 \mathrm{~m}$ stretches), structured shallow water zones (three $30 \mathrm{~m}$ stretches), three nature-like fish passes (with three $30 \mathrm{~m}$ stretches in each of them), and the former river course below the spillway (old Günz, with five $30 \mathrm{~m}$ stretches). The spatial scale of the assessed habitats is attributed to the pool/riffle system as described by Frissell et al. [19]. In each of the habitats, multiple $30 \mathrm{~m}$ stretches were electrofished and important physico-chemical variables, comprising current speed and water depth, temperature in the free flow (further referred to as temperature), dissolved oxygen, $\mathrm{pH}$-value (further referred to as $\mathrm{pH}$ ), and electric conductance were collected. All of the habitats are fully interconnected and fish could freely choose habitats according to their preferences. To the best of our knowledge, in this river stretch, no recent fish stocking took place.

\subsection{Restoration Actions in the Compared Habitats}

\subsubsection{Bank Habitats (BH)}

Within the main river Günz, as previously described in Pander \& Geist [3,4], the restoration of the stream bank of the main channel included the introduction of dead wood (HD), shallow water zones (HC), boulders with different void sizes between them (HB), as well as overhanging bank vegetation (HA). These types comprise all available bank habitats in the channelized section of the study river except for the juvenile habitats as described below. HA is built with a bank enforcement of boulders $(40 \mathrm{~cm} \times 80 \mathrm{~cm})$ constructed in a $45 \%$ bank angle. In this habitat, natural overhanging riparian wood, in combination with an understorey of shrub vegetation, is allowed to develop. HB is made out of the same bank reinforcement as HA with the same bank angle, but it has only slightly overhanging shrubs as bank vegetation. HC comprises smaller boulders $(20 \mathrm{~cm} \times 40 \mathrm{~cm})$. This habitat is built with a $1.0 \mathrm{~m}$ to $1.5 \mathrm{~m}$ wide berme creating a shallow water zone with a depth range on the berme of $5 \mathrm{~cm}$ to $25 \mathrm{~cm}$. The terrestrial part of the embankment is covered by grassland with no shrub vegetation. HD is constructed with a similar structure than HC, but additionally a deadwood fascine (anchored by steel wires) was placed on the edge of the berme where the water gets deeper again. The man-made fascine comprises a diameter of roughly $1.0 \mathrm{~m}$ to $1.2 \mathrm{~m}$ and it is about $15.0 \mathrm{~m}$ long (Figure 3) [3,4]. 
A

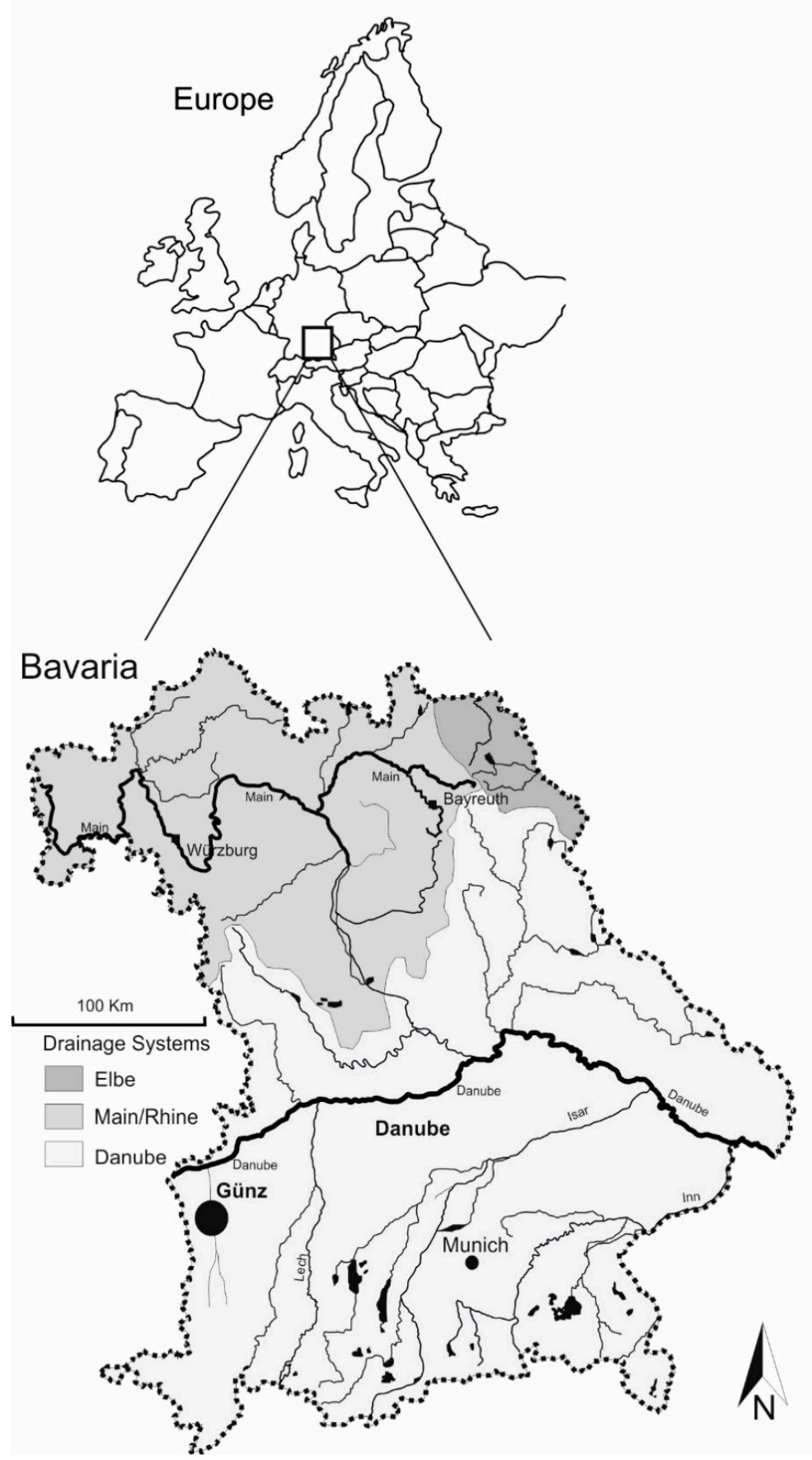

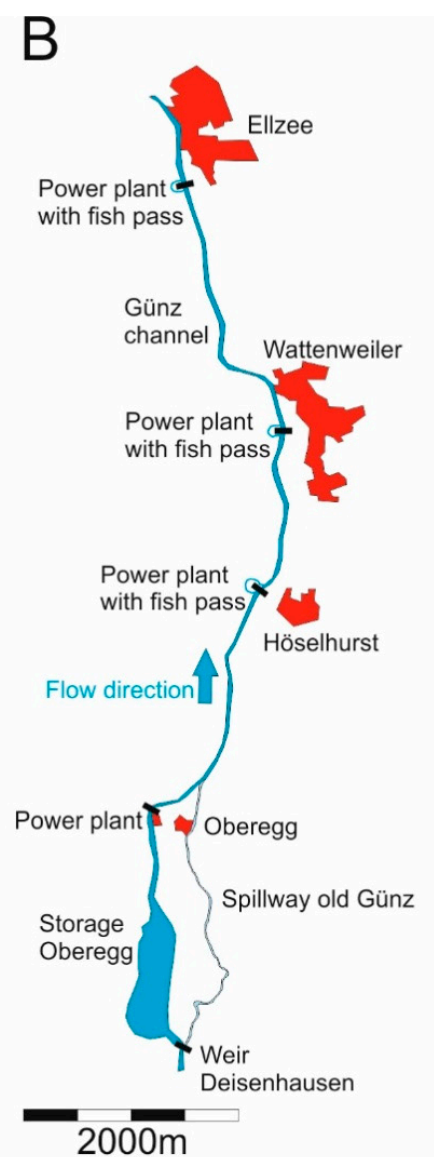

C Ellzee power plant with fish pass

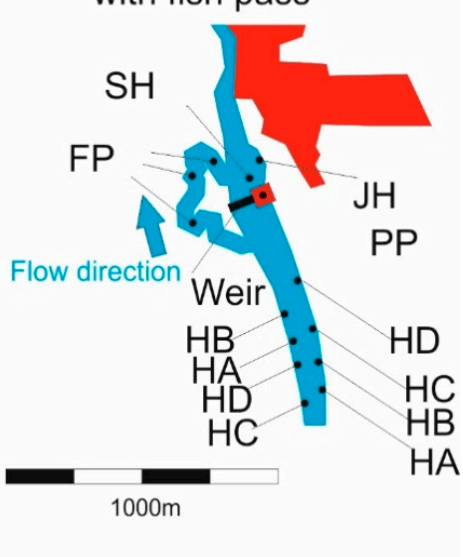

Figure 2. Map of Bavaria (Germany) of the Danube, Main/Rhine and Elbe drainages highlighted in different shadings and the location of the study area at the Günz river (A). (B) main channel of the study river with the power plants and villages (marked in red) Ellzee, Wattenweiler, Höselhurst, the three assessed fish passes and the former river course "old Günz" below the spillway with its diversion at the weir Deisenhausen and the confluence near the village of Oberegg. (C) detail of the power plant Ellzee (PP) with adjacent weir and the location of different sampling sites, such as $\mathrm{SH}=$ fast flowing instream habitat with gravel, $\mathrm{JH}=$ structured shallow water zone, and $\mathrm{FP}$ = nature like fish pass. HA, $\mathrm{HB}, \mathrm{HC}$, and $\mathrm{HD}$ are all bank habitats $(\mathrm{HB})$ as described in Figure 3. Please note, that part $\mathrm{C}$ of the Figure indicates an example of the randomly distributed habitat type $\mathrm{BH}$ throughout the main channel of the river Günz. 

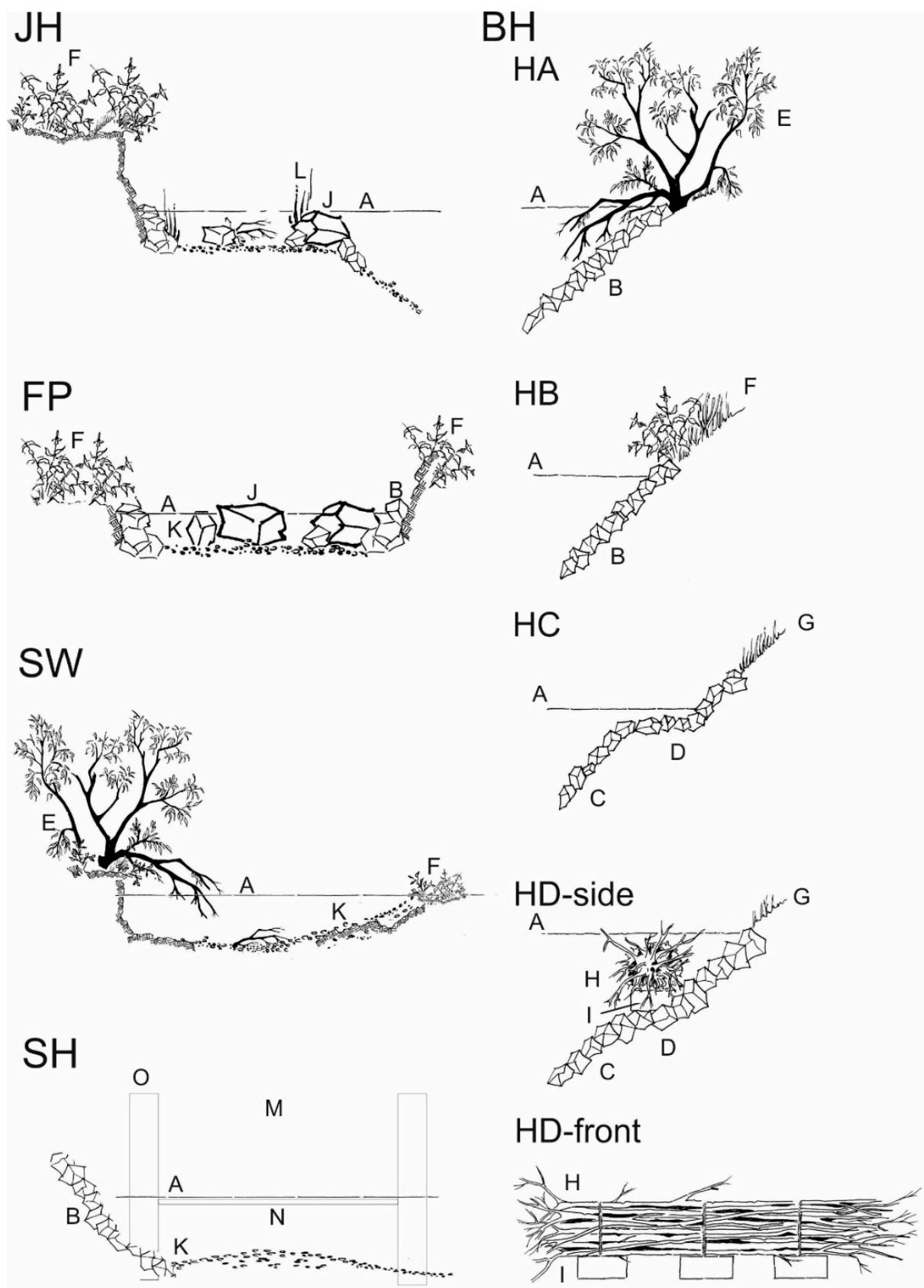

Figure 3. Magnification of the five different assessed habitat types of the river Günz. All drawings are lateral cuts and are without scale. $\mathrm{JH}=$ structured shallow water zone [18], $\mathrm{BH}=$ bank habitats (with the four different designs HA, HB, HC, and HD as described above and in Pander and Geist $[3,4]$ ), $\mathrm{SW}=$ former river course below the spillway, $\mathrm{SH}=$ fast flowing instream habitat with gravel, $\mathrm{FP}=$ nature like fish pass. $\mathrm{HA}=$ boulder rip-rap with natural grown riparian wood, $\mathrm{HB}=$ boulder rip-rap with shrubs, HC = benched boulder rip-rap with grass vegetation, HD-side = side-view of the deadwood fascine with its positioning on the rip-rap, HD-front = front-view indicating the structure of deadwood fascine and the anchoring. Habitat features A-I are also describes in Pander and Geist [3,4] with "A = water surface level, B = boulder rip-rap with limestone $40 \mathrm{~cm}-80 \mathrm{~cm}$ size, $\mathrm{C}=$ boulder rip-rap with limestone $20 \mathrm{~cm}-40 \mathrm{~cm}$ size, $\mathrm{D}=$ benched bank reinforcement, $\mathrm{E}$ = natural grown riparian wood, $\mathrm{F}$ = natural grown shrubs, $\mathrm{G}$ = sowed grass mixture, $\mathrm{H}=$ artificial made dead wood fascine, $\mathrm{I}=$ concrete block to anchor the fascine." J = limestone boulder $80 \mathrm{~cm}-100 \mathrm{~cm}$ size, $\mathrm{K}=$ introduced gravel (SW = grain size $8 \mathrm{~mm}-32 \mathrm{~mm}, \mathrm{JH}$ and $\mathrm{SH}=$ grain size $<0.85 \mathrm{~mm}-56 \mathrm{~mm}$ with less than $12 \%$ grain size $<0.85 \mathrm{~mm}$, $\mathrm{FP}=$ grain size $32 \mathrm{~mm}-63 \mathrm{~mm}), \mathrm{L}=$ macrophytes, $\mathrm{N}=$ turbine outlet, $\mathrm{M}=$ power house of the power plant, $\mathrm{O}=$ guiding walls at the turbine outlet. 


\subsubsection{Structured Shallow Water Zones (JH)}

This habitat is also located in the main channel of the Günz, below the fast flowing gravel habitat, as described above. The intention to build this habitat was to provide areas with low current where larval fish emerging from fast flowing habitat upstream can further develop. In principle, it is constructed as a highly engineered shallow water habitat carved with an excavator into the trapezoidal cross section of the river embankment. Like the $\mathrm{BH}$ types, it comprises a relatively steep bank angle $>45 \%$. At the bottom of the bank rip-rap, there are larger boulders set to avoid bank erosion $(80 \mathrm{~cm}-100 \mathrm{~cm})$. The adjacent rip-rap (boulder size $40 \mathrm{~cm}-80 \mathrm{~cm}$ ) of the remaining river-bank is carried out like the habitat $\mathrm{BH}$. The JH is separated from the main channel of the Günz by single boulders as used at the beginning of the rip-rap $(80 \mathrm{~cm}-100 \mathrm{~cm})$. These large boulders have the intention to reduce the current inside the habitat and to avoid erosion processes, which may otherwise deepen the JH. The boulders are placed that fish can freely move between this habitat and the main channel of the river. In this habitat, gravel was introduced in order to improve the substratum quality and the river bottom was additionally structural enriched by placing single boulders in combination with dead trees, cut from the river bank (coarse woody debris) (Figure 3). The minimum and maximum size of this habitat type ranges between $125 \mathrm{~m}^{2}$ and $225 \mathrm{~m}^{2}$. For a detailed description of this habitat type, also see [18].

\subsubsection{Fast Flowing Instream Habitat with Gravel (SH)}

This instream habitat is located in the main channel of the Günz in direct spatial proximity downstream of the turbine outlets of the power plants Ellzee, Wattenweiler, and Höselhurst. The intention of the restoration of this habitat was to create fast flowing habitats with water depths $<1 \mathrm{~m}$ and with coarse gravel at the river bottom, since such structures are usually scarce in HMWBs. It was intended that this habitat should serve as a spawning habitat for rheophilic fishes such as C. nasus, as well as an important feeding habitat for this species because of periphyton growth. The deeper sections in this habitat were filled with gravel (grain size 0-56 mm) with a maximum fine content $(<0.85 \mathrm{~mm})$ of $<12 \%$. It was necessary to use $30 \mathrm{~m}^{3}-130 \mathrm{~m}^{3}$ of gravel to reach water depths between $80 \mathrm{~cm}-150 \mathrm{~cm}$ (Figure 3). The gravel was put in and was distributed from the maintenance road at the river bank with an excavator. Thickness of the introduced substratum layer was at minimum $40 \mathrm{~cm}$.

\subsubsection{Nature Like Fish Passes (FP)}

The fish passes were built, besides the intention to restore fish migration, for the purpose of compensating the structural deficits of the main channel of the Günz. All of the fish passes comprised a nature-like construction design. Construction was focused on creating high variability of water depth and current speed. Additionally, the FP were structurally enriched using boulders of different sizes as mentioned for the other habitats (Figures 2 and 3). Sinuosity and channel slope of the water courses used to construct the FP are typical for rivers in this landscape with less than $1 \mathrm{~m}^{3} \cdot \mathrm{s}^{-1}$ discharge. Specific habitat requirements for C. nasus and B. barbus, the two target species of restoration, were only considered in the context of their migration, but not for creating additional habitats. The lengths of the fish passes were between FP Höselhurst 125 m, FP Wattenweiler 188 m, and FP Ellzee 233 m, respectively, and they all had a rectangular entrance $(160 \mathrm{~cm} \times 75 \mathrm{~cm})$, a mean depth of $55 \mathrm{~cm}$, and they were not shaded by tree-cover, only overhanging shrubs as bank vegetation was present. The bottom of the fish pass was completely covered by an introduced gravel mixture of the grain size $32 \mathrm{~mm}-63 \mathrm{~mm}$. The upstream connection is closely placed to the weir and the downstream connection is located ca. $30 \mathrm{~m}$ downstream of the weir. The discharge in all fish passes is fixed to $0.3 \mathrm{~m}^{3} \cdot \mathrm{s}^{-1}$. All the fish passes were constructed following the recommendations of the German national standard for restoring fish migration [28].

\subsubsection{Former River Course below the Spillway (SW)}

In addition to the newly created fish passes and the habitats of the main channel, we also assessed the "old Günz", because its present use as a spillway and its potential suitability as habitat for critical 
life stages such as spawning or juvenile growth within the Günz system. The "old Günz" below the spillway is the former river bed and it is running $2.6 \mathrm{~km}$ parallel to the main channel of the Günz that is today used for hydropower generation (Figures 2 and 3). It was partly reconstructed by removing bank stabilisation, removing an abandoned weir, improving substrate quality with gravel introductions of a standardised mixture (grain size $8 \mathrm{~mm}-16 \mathrm{~mm}$ and $16 \mathrm{~mm}-32 \mathrm{~mm}$ ) and the discharge can be managed dynamically throughout the year under the restriction not to affect hydropower production. At mean flow conditions, the discharge is $0.7 \mathrm{~m}^{3} \cdot \mathrm{s}^{-1}$ and only if the maximum capacity of the turbines is reached (over $30 \mathrm{~m}^{3} \cdot \mathrm{s}^{-1}$ ) all additional discharge is released through the spillway. Under extreme conditions, the discharge can be up to $100 \mathrm{~m}^{3} \cdot \mathrm{s}^{-1}$. The annual maximum discharge however, is between $30 \mathrm{~m}^{3} \cdot \mathrm{s}^{-1}$ and $50 \mathrm{~m}^{3} \cdot \mathrm{s}^{-1}$ in this habitat and occurs likely once a year. Since the old original river bed of the Günz was formed by a higher mean discharge, it looks too wide and it comprises a lack of river bed dynamics under low flow conditions.

\subsection{Measurement of Physico-Chemical Habitat Characteristics}

To test for differences of abiotic habitat conditions between habitats, water depth (WD), current speed $5 \mathrm{~cm}$ below the water surface (CSS), and $5 \mathrm{~cm}$ above the substratum (CSB), temperature (T), dissolved oxygen $\left(\mathrm{O}_{2}\right), \mathrm{pH}$, and electric conductance $(\mathrm{EC})$ were recorded. Measurements were shortly taken after the fish sampling in each of the habitat replicates, at the upper end of the habitat and approximately in two meters distance from the riverbank. WD was measured with a level pole to the nearest $\mathrm{cm}$. Current speed at the surface as well as above the substratum was recorded with a handheld flow meter (Höntzsch Instrumente, Waiblingen, Germany). Water depth and current speed were measured in three cross sections in each habitat, as described in more detail in Pander and Geist [3], Pander, Mueller, and Geist [21]. $\mathrm{O}_{2}, \mathrm{~T}, \mathrm{EC}$, and $\mathrm{pH}$ were recorded in the free flowing water of each replicate in each habitat type with a Multi 3430 SET G (WTW, Weilheim, Germany). Macrophytes (M) and coarse woody debris (CWD) can be important structural elements in rivers for many aquatic species [29-31]. Therefore, the coverage of $\mathrm{M}$ and the amount of CWD were estimated in each replicates of each habitat type. M coverage was estimated, as described in Braun-Blanquet [32]. CWD was estimated in 5\% iterations. In the case of less than $<5 \%$ coverage of CWD, the classification was done in $1 \%$ steps.

\subsection{Fish Sampling}

Since in the Günz system the most species including C. nasus and B. barbus spawn in April and May, and since this study focused on habitat use of spawners, early life stages and juveniles, the sampling of the fish community took place between April and August 2013. All the habitats of the main channel were fished with a portable electrofishing device based on a boat (EL 65 II, Grassl, Schoenau, Germany), following the procedure described in Pander and Geist [3]. All the habitats were sampled with the same electrofishing crew fishing from downstream to upstream within a $3 \mathrm{~m}$ distance to the bankside of the habitats. One person was steering the boat, one person was handling the anode and one person collected the stunned fish with a dipnet of $3 \mathrm{~mm}$ mesh size. The sampling was carried out within a five-hour period from 10 a.m.to 3 p.m. Due to their shallower water, habitats outside the main channel such as fish pass habitats and the former river course below the spillway were sampled with a smaller electrofisher (FEG 8000, EFKO Leutkirch i.A., Germany), following the same methodological approach. Fish from individual habitats were collected in plastic tanks with a supplementation of oxygen to ensure fish health. All fish individuals were measured to the nearest $\mathrm{cm}$ total length. Fish of $10 \mathrm{~cm}$ or more were individually weighed to the nearest gram. Since an accurate weighing of the high numbers of fish $<10 \mathrm{~cm}$ was not feasible in the field, an individual for each fish species determined body mass index was used to calculate the individual fish weight. The BMI for the species of the Günz was developed in Pander and Geist [3]. Therefore, a representative number of at least 15 fish was weighed in order to determine the BMI $\left(\right.$ BMI $=\left(\right.$ weight $(\mathrm{g}) /$ total length $\left.\left.^{3}(\mathrm{~cm})\right) \times 100\right)$. 


\subsection{Statistical Analysis}

For univariate statistics, abiotic data were checked for normality and homogeneity of variances with the Shapiro-Wilk-test and the Levene-test. Subsequently, Kruskal-Wallis-tests and Bonferroni-corrected post-Hoc pairwise Mann-Whitney-U-tests were run, since the data were not normally distributed. The univariate testings' were performed using the program $\mathrm{R}$ (www.r-projekt. org). For fish abundance data a catch per unit effort (CPUE) expressed in individuals $/ 300 \mathrm{~m}^{2}$ was calculated and fish biomass was calculated in $\mathrm{kg} / \mathrm{ha}$. In order to detect whether larger or smaller fish use distinctive habitat types, the mean fish biomass in each habitat was calculated in $\mathrm{g}$ and fish were assigned to size classes. To test for population developments of the specialised target species $C$. nasus and B. barbus as well as for the most common generalist species $S$. cephalus in the study area, fish data was grouped into distinctive size classes $(<5 \mathrm{~cm}, 6-10 \mathrm{~cm}, 11-20 \mathrm{~cm}, 21-30 \mathrm{~cm}$, $31-40 \mathrm{~cm}$, and $>40 \mathrm{~cm}$ ) and plotted over all habitats and for each habitat type separately. Fish diversity distribution was measured as Shannon-diversity [33]), as well as Evenness [34]. To identify ecological integrity of the fish community in the five riverine habitat types, a trait classification of the current preference (indifferent, rheophilic, and stagnophilic) of the individual fish species was done following the classification scheme of Zauner and Eberstaller [35]. The fish regions index (FRI, [36]) was plotted to indicate the rheophilic community composition in the different habitat types. One-way Analysis of Similarities (ANOSIM) based on Bray-Curtis distance derived from fish abundance data were performed to detect multivariate differences of the fish community composition between $\mathrm{BH}, \mathrm{JH}, \mathrm{SH}$, SW, and FP habitats. Potential effects of the measured abiotic habitat variables, as described above on fish community composition were assessed with Biota-Environmental Stepwise Matching (BEST) analyses. In these analyses, the same fish abundance data as for the ANOSIM were used as response variables, and all environmental variables were used as predictors. For visualisation of the data, non-metric-multidimensional-scaling-plots (NMDs) were computed. Additionally, length-frequency data of all fish species were used and plotted as bubbles in the NMDs plot, to visualize differences in habitat preferences of fishes in relation to their size (minimum recorded size of fish to $10 \mathrm{~cm}$ and fish $>30 \mathrm{~cm}$ to maximum recorded size). A Similarity-Percentage-Analysis (SIMPER) was computed to detect common and steadily occurring fish species in the five assessed habitat types. The SIMPER analysis determines in this case the relative contribution of fish species to the ingroup-similarity that could be found in $\mathrm{BH}, \mathrm{JH}, \mathrm{SH}, \mathrm{SW}$, and FP habitats, respectively [37]. For all multivariate analyses, the program PRIMERv6 (Plymouth Marine Laboratories, Plymouth, UK) was utilized. Significance for univariate as well as multivariate testings' was accepted for $p \leq 0.05$.

\section{Results}

\subsection{Abiotic Habitat Characteristics}

The five habitat types differed strongly in their abiotic habitat conditions and morphology (Table 1 , Figure 3). HB and SH habitats were deepest with a mean water depth $>1 \mathrm{~m}$, whilst JH, FP, and SW habitats comprised a mean water depth $<50 \mathrm{~cm}$ with $\mathrm{JH}$ being the shallowest habitat with a mean water depth of $27 \mathrm{~cm}$. CSS and CSB was highest in SH and lowest in BH and JH and ranged generally between $0.01 \mathrm{~m} \cdot \mathrm{s}^{-1}$ and $1.10 \mathrm{~m} \cdot \mathrm{s}^{-1}$. FP and SW did not differ in CSS and CBS and they were in the mid-range when compared to all the assessed habitats with about $0.3 \mathrm{~m} \cdot \mathrm{s}^{-1} \cdot \mathrm{O}_{2}$ was measured in all habitats, always exceeding the minimum tolerance of all species detected in the study area $\left(6.4 \mathrm{mgl}^{-1}-9.0 \mathrm{mgl}^{-1}\right)$, with one exception in JH habitats where the values could have been too low for salmonids and Cottus gobio L. (bullhead). Coolest temperatures were measured in SW and FP habitats $\left(15.5^{\circ} \mathrm{C}\right.$ and $\left.15.6^{\circ} \mathrm{C}\right)$, whilst temperatures in $\mathrm{BH}, \mathrm{JH}$, and $\mathrm{SH}$ in the main channel were up to $2.5^{\circ} \mathrm{C}$ warmer (Table 1). In addition, there was also a significant difference with slightly higher EC values in BH and SH (ranging from 594-624 $\mu \mathrm{S} \mathrm{cm}^{-1}$ ), which are habitats of the main channel when compared to FP and SW $\left(595-603 \mu \mathrm{S} \mathrm{cm}^{-1}\right)$. pH values differed significantly throughout the habitats ranging from 7.8 measured in $\mathrm{SW}$ to 9.4 measured in $\mathrm{JH}$ habitats. CWD as mean was highest in JH (10\%) and SW (9\%), followed by $\mathrm{BH}(5 \%)$ and maximum 
values of 35\% CWD were measured in replicates of $\mathrm{BH}$ habitats with the deadwood fascine. In $\mathrm{SH}$ and FP, none or almost none CWD was detected. Mean macrophyte coverage was the highest in JH (12\%) and $\mathrm{BH}(5 \%)$ habitats and was $<1 \%$ in $\mathrm{SH}, \mathrm{FP}$, and SW habitats (Table 1 ).

Table 1. Abiotic habitat variables measured at the five assessed habitat types: $\mathrm{WD}=$ water depth, CSS = current speed measured $5 \mathrm{~cm}$ below the water surface $\left(\mathrm{ms}^{-1}\right), \mathrm{CSB}=$ current speed measured $5 \mathrm{~cm}$ above the river bottom $\left(\mathrm{ms}^{-1}\right), \mathrm{O}_{2}=$ dissolved oxygen concentration $\left(\mathrm{mgl}^{-1}\right), \mathrm{T}=$ Water temperature in the free flow $\left({ }^{\circ} \mathrm{C}\right), \mathrm{EC}=$ electric conductance $\left(\mu \mathrm{Scm}^{-1}\right), \mathrm{pH}=\mathrm{pH}$-value, $\mathrm{M}=$ coverage of macrophytes $(\%), \mathrm{CWD}=$ coarse woody debris coverage $(\%), \mathrm{CG}=$ coarse gravel introduced with grain size. Upper layer $=$ mean value, lower layer $=$ minimum to maximum values. $\mathrm{JH}, \mathrm{BH}, \mathrm{SH}, \mathrm{SW}$, and FP refer to the habitat types, as described in Figure 3. Upper case letters (a, b, c, d, e) indicate significant differences $(p<0.05)$ among habitat types.

\begin{tabular}{|c|c|c|c|c|c|c|c|c|c|}
\hline Habitat & WD & CSS & CSB & $\mathrm{O}_{2}$ & $T$ & EC & $\mathrm{pH}$ & CWD & $\mathbf{M}$ \\
\hline \multirow[t]{2}{*}{$\mathrm{JH}$} & $27^{a}$ & $0.19^{a}$ & $0.13^{a}$ & $6.4^{\mathrm{a}}$ & $17.4^{\mathrm{a}}$ & $596^{a}$ & $9.4^{\mathrm{a}}$ & $10^{a}$ & $12^{a}$ \\
\hline & $5-27$ & $0.01-0.40$ & $0.01-0.29$ & $6.2-6.6$ & $16.6-18.0$ & $589-601$ & $9.1-9.6$ & 5-15 & 5-15 \\
\hline \multirow[t]{2}{*}{$\mathrm{BH}$} & $128^{\mathrm{b}}$ & $0.10^{b}$ & $0.06^{b}$ & $7.4^{b}$ & $17.3^{\mathrm{a}}$ & $609^{b}$ & $8.7^{b}$ & $5^{a}$ & $5^{b}$ \\
\hline & 83-175 & $0.01-0.30$ & $0.01-0.30$ & $7.0-7.7$ & $16.6-18.0$ & $594-624$ & $6.9-9.8$ & $0-35$ & $0-15$ \\
\hline \multirow[t]{2}{*}{$\mathrm{SH}$} & $116^{b c}$ & $0.75^{c}$ & $0.39^{c}$ & $7.3^{c}$ & $17.4^{\mathrm{a}}$ & $615^{c}$ & $8.3^{c}$ & $0^{b}$ & $0.3^{c}$ \\
\hline & 83-154 & $0.24-1.10$ & $0.11-0.90$ & $7.1-7.6$ & $16.6-18.0$ & $594-624$ & $7.8-8.5$ & 0 & $0-1$ \\
\hline \multirow[t]{2}{*}{ FP } & $55^{\mathrm{d}}$ & $0.35^{\mathrm{ad}}$ & $0.24^{\mathrm{ad}}$ & $9.0^{\mathrm{c}}$ & $16.1^{b}$ & $599^{d}$ & $8.2^{\mathrm{d}}$ & $0.5^{c}$ & $1^{\mathrm{d}}$ \\
\hline & 24-102 & $0.01-0.99$ & $0.01-1.08$ & 7.7-9.9 & $15.6-16.5$ & 595-601 & $8.1-8.3$ & $0-1$ & $1-3$ \\
\hline \multirow[t]{2}{*}{ SW } & $48^{\mathrm{d}}$ & $0.32^{d}$ & $0.30^{\mathrm{dc}}$ & $8.8^{c}$ & $16.0^{\mathrm{c}}$ & $599^{d}$ & $7.8^{\mathrm{e}}$ & $9^{a b}$ & $0.6^{\mathrm{e}}$ \\
\hline & 12-105 & $0.03-0.87$ & $0.02-1.00$ & $8.5-9.8$ & $15.5-16.5$ & $594-603$ & $7.7-8.7$ & $3-15$ & $0-1$ \\
\hline
\end{tabular}

\subsection{Fish Habitat Use}

A total of 27 fish species from nine families comprising a total number of 5.553 individuals were recorded (Table Si1). The fish community in the Günz system comprised mainly cyprinids with 17 species and 5.087 individuals. 14 species with $63 \%$ of the individuals caught were classified as indifferent, nine species as rheophil (26\% individuals), and four species ( $11 \%$ individuals) were typically stagnophil. Between the five assessed habitat types, pronounced differences in fish community were evident. Greatest species richness was detected in SW (21 species), BH (21), JH (19), SH (18), and FP (17). In the SW habitats, also the highest number of individuals (664 individuals) was caught whilst in FP habitats highest fish biomass (1043 kg/ha) was detected. In $\mathrm{BH}$, the lowest density of fish was detected and in JH the lowest fish biomass and the lowest mean fish weight was detected. Shannon diversity was highest in JH, followed by SW and SH habitats, and Evenness was highest in $\mathrm{JH}$, followed by SH and SW habitats. FRI was lowest (5.70 indicating rheophilic conditions) in FP, followed by SW and SH habitats (Table 2).

The multivariate analysis of the fish community in all habitats revealed significant differences (ANOSIM, $\mathrm{R}=0.63, p<0.001$ ) between $\mathrm{SW}, \mathrm{BH}$ and $\mathrm{JH}$ and all other habitat types, respectively. Differences between SH-FP and SW-FP, however, were not statistically significant $(p>0.05$, Figure 4A, Table 3). The differences between habitats were evident from both the community composition differences, but also strongly from the size differences of the fish caught. In some habitats, mostly small specimens $<10 \mathrm{~cm}$ were caught (particularly SW, JH, and some of the $\mathrm{BH}$, especially the dead wood fascine), whilst in other habitats the number of fish $>30 \mathrm{~cm}$ was greatest $(\mathrm{SH}, \mathrm{FP}$, some replicates of SW and some of the BH particularly the natural bank vegetation) (Figure 4B,C). The SIMPER-analysis (Figure 5) revealed a common and distinct set of fish species for each habitat type. SW habitats were characterised by small body-sized fish, such as Phoxinus phoxinus L. (Eurasian minnow, $<5 \mathrm{~cm}$ and 6-10 cm), small B. barbus $(<5 \mathrm{~cm})$, and $S$. cephalus $(6-10 \mathrm{~cm}), \mathrm{SH}$ habitats by large and medium sized B. barbus $(>40 \mathrm{~cm}, 21-30 \mathrm{~cm})$, medium sized Salmo trutta L. (brown trout, 21-30 cm), and large C. nasus $(>40 \mathrm{~cm})$, JH habitats by small fish, such as $S$. cephalus $(6-10 \mathrm{~cm})$, Rhodeus amarus B. (European bitterling, <5 cm), Gasterosteus aculeatus L. (three-spined stickleback, $<5 \mathrm{~cm}$ ), Gobio gobio L. (gudgeon, 6-10 cm), and Barbatula barbatula L. (stone loach, 6-10 cm), FP habitats by medium sized B. barbus 
$(11-20 \mathrm{~cm})$, S. cephalus $(11-30 \mathrm{~cm})$, and $S$. trutta $(21-30 \mathrm{~cm})$. BH habitats were characterised by R. amarus $(<5 \mathrm{~cm})$, Rutilus rutilus L. (common roach, 11-20 cm), Perca fluviatilis L. (European perch, 11-20 cm), and $S$. cephalus $(6-20 \mathrm{~cm})$.

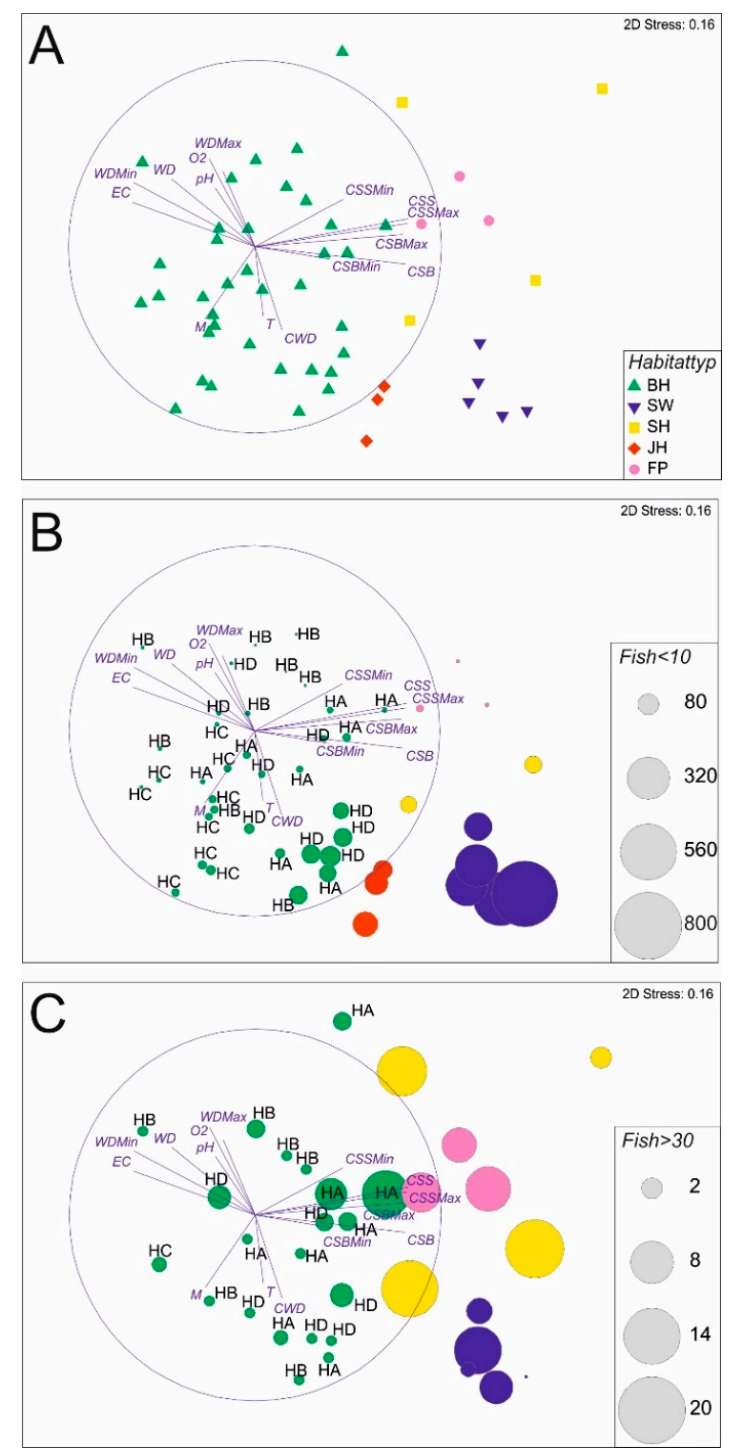

Figure 4. Fish community composition (A) in the five different habitat types plotted as a non-metric multidimensional scaling (NMDS). JH = structured shallow water zones displayed in red rhombi, $\mathrm{BH}$ = bank habitats (HA, HB, HC, and HD) in green triangles, $\mathrm{SW}=$ former river course below the spillway in dark blue triangles, $\mathrm{SH}=$ fast flowing instream habitat with gravel in yellow squares, $\mathrm{FP}=$ nature like fish pass in pink dots. $\mathrm{JH}, \mathrm{BH}, \mathrm{SW}, \mathrm{SH}$, and $\mathrm{FP}$, refer also to the five habitat types, as described above (Figure 3). Circles in part B and C of Figure 4 are proportional in size to the number of caught fish (N) per individual replicate of the habitat. Individuals $<10 \mathrm{~cm}=$ fish individuals smaller than $10 \mathrm{~cm}$ total length (part B) and Individuals $>30 \mathrm{~cm}=$ fish individuals larger than $30 \mathrm{~cm}$ total length (part C). $\mathrm{WD}=$ water depth, CSS = current speed measured $5 \mathrm{~cm}$ below water surface $\left(\mathrm{ms}^{-1}\right), \mathrm{CSB}=$ current speed measured $5 \mathrm{~cm}$ above river bottom $\left(\mathrm{ms}^{-1}\right), \mathrm{O}_{2}=$ concentration of dissolved oxygen $\left(\mathrm{mgl}^{-1}\right)$, $\mathrm{T}=$ temperature $\left({ }^{\circ} \mathrm{C}\right), \mathrm{EC}=$ electric conductance $\left(\mu \mathrm{Scm}^{-1}\right), \mathrm{pH}=\mathrm{pH}$-value, $\mathrm{M}=$ estimated macrophyte coverage $(\%), \mathrm{CWD}=$ estimated coverage of coarse woody debris $(\%), \mathrm{CG}=$ coarse gravel introduced, Min = minimum values, Max = maximum values. All the measured Physico-chemical variables were correlated on the NMDs plot and printed as blue lines. Length of the lines is proportional to the degree of correlation with the arrangement of fish community data (the blue circle indicates $100 \%$ correlation). 
Table 2. Overview of the results in the five assessed habitat types $\mathrm{JH}=$ structured shallow water zone, $\mathrm{BH}=$ bank habitats, $\mathrm{SW}=$ former river course below the spillway, $\mathrm{SH}=$ fast flowing instream habitat with gravel, $\mathrm{FP}=$ nature like fish pass. $\mathrm{S}=$ number of species, $\mathrm{CPUE}=$ catch per unit effort of number of individuals (Individuals $\left./ 300 \mathrm{~m}^{2}\right), \mathrm{M}=$ biomass $(\mathrm{kg} / \mathrm{ha}), \mathrm{MFM}=$ mean fish weight $(\mathrm{g})$, $\mathrm{H}=$ Shannon-Index, $\mathrm{J}=$ Evenness, FRI = fish regions index (Dußling et al. 2005 [38]).

\begin{tabular}{|c|c|c|c|c|c|c|c|}
\hline Habitat & $S$ & $\begin{array}{c}\text { CPUE } \\
\text { (Individuals } / 300 \mathrm{~m}^{2} \text { ) }\end{array}$ & $\begin{array}{c}\mathrm{M} \\
(\mathrm{kg} / \mathrm{ha})\end{array}$ & $\begin{array}{l}\text { MFM } \\
\text { (g) }\end{array}$ & $\mathbf{H}$ & $\mathbf{J}$ & FRI \\
\hline $\mathrm{JH}$ & 19 & 292 & 86 & 8 & 2.48 & 0.84 & 6.12 \\
\hline $\mathrm{BH}$ & 21 & 80 & 135 & 55 & 1.82 & 0.67 & 6.48 \\
\hline SW & 21 & 664 & 416 & 15 & 2.12 & 0.70 & 5.75 \\
\hline $\mathrm{SH}$ & 18 & 132 & 722 & 165 & 2.09 & 0.77 & 6.02 \\
\hline $\mathrm{FP}$ & 17 & 207 & 1043 & 135 & 1.58 & 0.56 & 5.70 \\
\hline
\end{tabular}

Table 3. R-values and $p$-values resulting from the Analysis of Similarities (ANOSIM) detected for comparisons of the fish community compositions between the five assessed habitat types $\mathrm{JH}=$ structured shallow water zones, $\mathrm{BH}=$ bank habitats, $\mathrm{SW}=$ former river course below the spillway, $\mathrm{SH}=$ fast flowing instream habitat with gravel, $\mathrm{FP}=$ nature like fish pass.

\begin{tabular}{ccc}
\hline Comparisons & $\mathbf{R}$ & Significance Level $\boldsymbol{p}$ \\
\hline BH-SW & 0.772 & $<0.001$ \\
BH-SH & 0.687 & $<0.001$ \\
BH-JH & 0.443 & $<0.01$ \\
BH-FP & 0.663 & $<0.001$ \\
SW-SH & 0.619 & $<0.01$ \\
SW-JH & 1.000 & $<0.05$ \\
SW-FP & 1.000 & $<0.05$ \\
SH-JH & 0.481 & $>0.05$ \\
SH-FP & -0.093 & $>0.05$ \\
JH-FP & 1.000 & $>0.05$ \\
\hline
\end{tabular}

None of the assessed habitat types alone comprised a full species inventory nor a population development with all size classes of the target species of restoration B. barbus and C. nasus. However, in combination of all habitat types, $B$. barbus was present in almost all size classes in relatively high numbers, whilst $C$. nasus still comprised a small population with serious lacks in distinctive size classes (Figure 6). In contrast, S. cephalus, a generalist species that is common in the river Günz, comprised a full and strong population, including all size classes. For each of these three species, different habitat types were important. Whilst the habitats in SW were very important for C. nasus and B. barbus concerning individuals under $10 \mathrm{~cm}, S$. cephalus also had high recruitment in BH habitats additionally comprising larger size classes $(11-20 \mathrm{~cm})$ there as well. FP Habitats were very important for larger size classes of the target species (C. nasus size class $11-20 \mathrm{~cm},>40 \mathrm{~cm}$ and B. barbus size class $11-20 \mathrm{~cm}$ ). For $C$. nasus, the habitat $\mathrm{SH}$ was additionally important for the largest size class $>40 \mathrm{~cm}$ (Figure 6). 


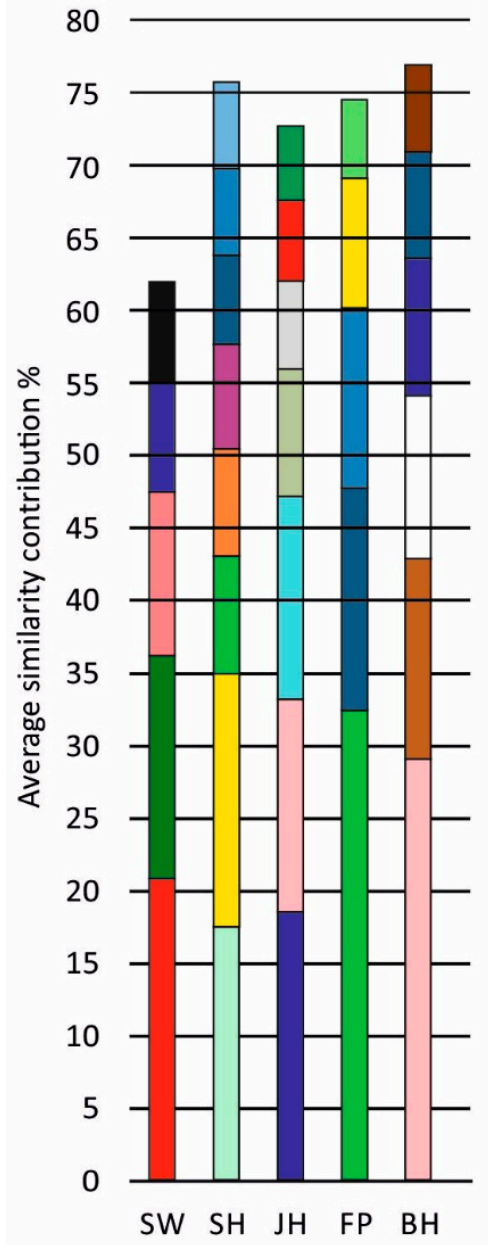

Phoxinus phoxinus $<5$

Phoxinus phoxinus 6-10

Barbus barbus $<5$

Barbus barbus 6-10

Barbus barbus 11-20

Barbus barbus 21-30

Barbus barbus $>40$

Squalius cephalus $<5$

Squalius cephalus 6-10

Squalius cephalus 11-20

Squalius cephalus 21-30

Squalius cephalus 31-40

Salmo trutta 21-30

Alburnus alburnus 11-20

Chondrostoma nasus $>40$

Rhodeus amarus $<5$

Gasterosteus aculeatus $<5$

Gobio gobio 6-10

Barbatula barbatula 6-10

Rutilus rutilus 6-10

Rutilus rutilus 11-20

Perca fluviatilis 11-20

Figure 5. Fish species contribution to ingroup-similarity in the five habitats detected by the SIMPER analysis. $\mathrm{JH}=$ structured shallow water zones, $\mathrm{BH}=$ bank habitats, $\mathrm{SW}=$ former river course below the spillway, $\mathrm{SH}=$ fast flowing instream habitat with gravel, and $\mathrm{FP}=$ nature like fish pass. Only species with a contribution to the overall ingroup-similarity of more than $5 \%$ are shown.

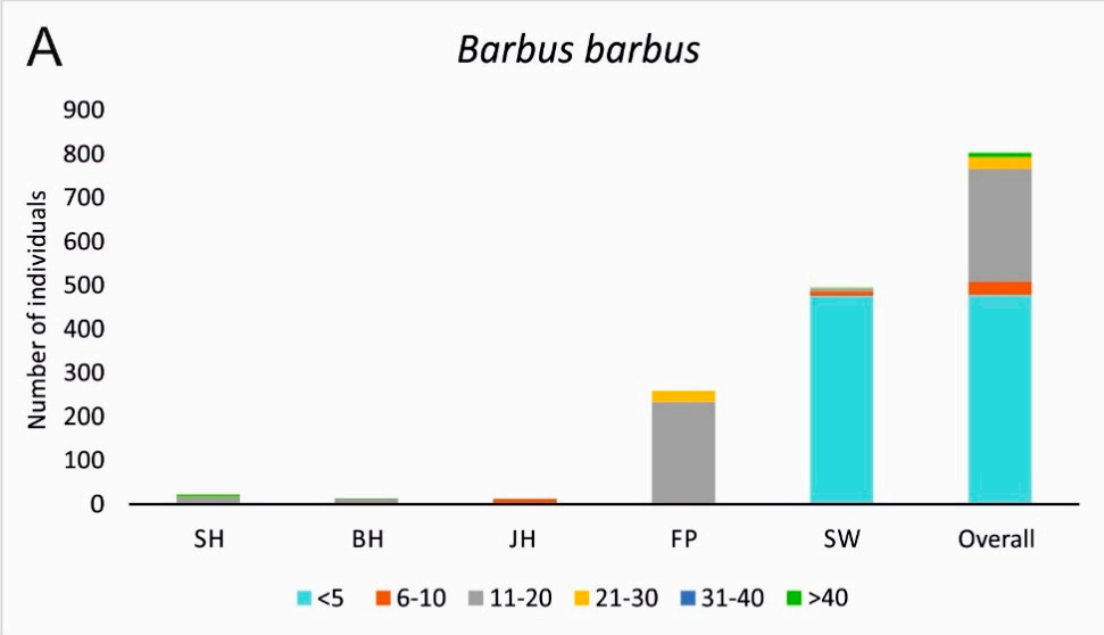

Figure 6. Cont. 


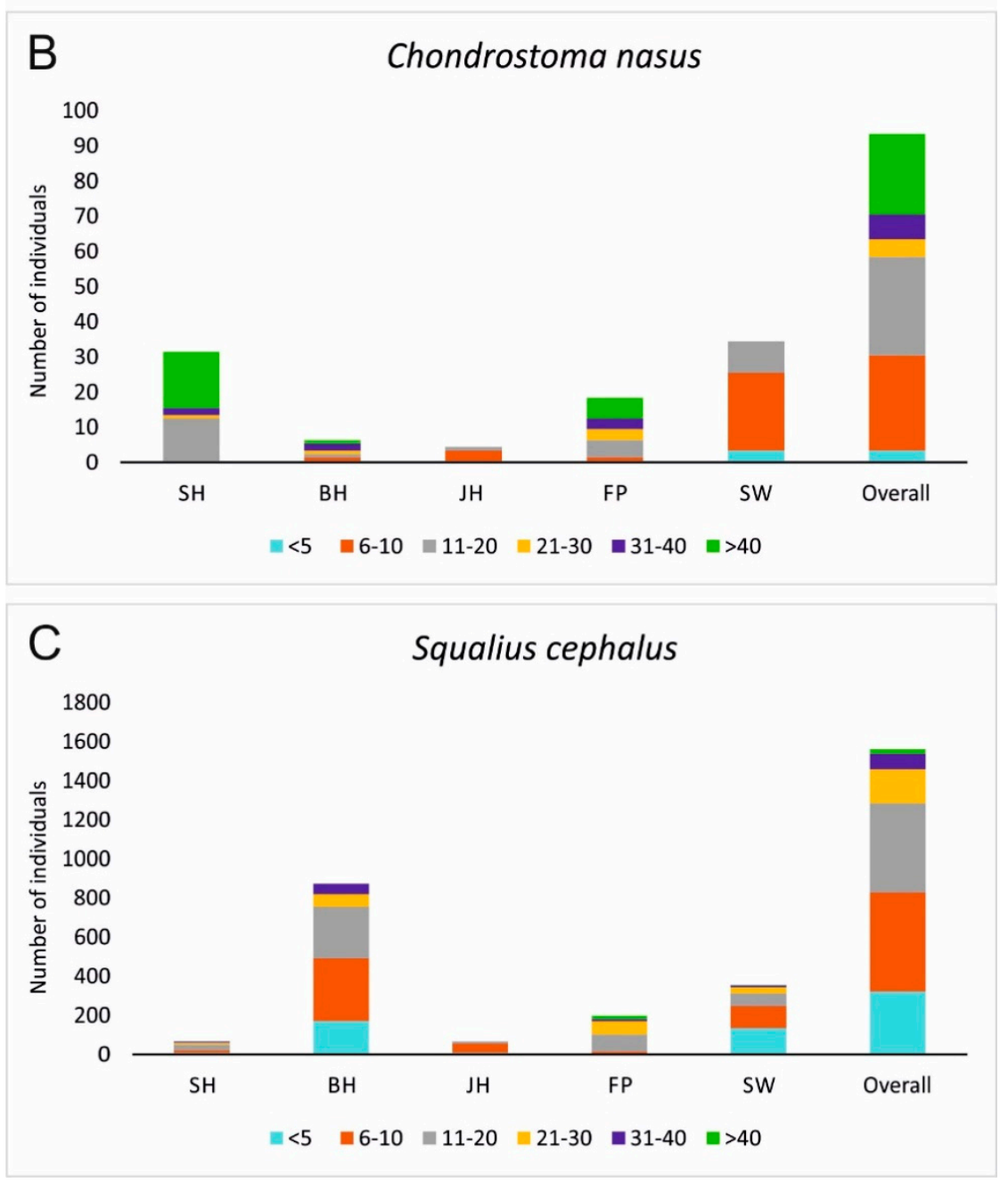

Figure 6. Fish population structures of Barbus barbus (A) and Chondrostoma nasus (B) displayed in different size classes for the five assessed habitat types. Additionally Squalius cephalus (C), a generalist species that is most common in the Günz and comprises a self-sustainable population is presented. SH = fast flowing instream habitat with gravel, $\mathrm{BH}=$ bank habitats, $\mathrm{JH}=$ structured shallow water zones, $\mathrm{FP}=$ nature like fish pass, $\mathrm{SW}=$ former river course below the spillway. $<5=$ size class of fish $5 \mathrm{~cm}$ and smaller, $6-10=$ individuals between $6 \mathrm{~cm}$ and $10 \mathrm{~cm}, 11-20=$ individuals between $11 \mathrm{~cm}$ and $20 \mathrm{~cm}$, 21-30 = individuals between $21 \mathrm{~cm}$ and $30 \mathrm{~cm}, 31-40=$ individuals between $31 \mathrm{~cm}$ and $40 \mathrm{~cm}$, and $>40$ = individuals with a total length of more than $40 \mathrm{~cm}$, Overall = result of the length distribution pooled over all habitats.

\section{Discussion}

Restoration in HMWBs is necessary, because they can contribute strongly to overall biodiversity in aquatic habitats and can harbour valuable and protected riverine fish species. However, habitat restoration in HMWBs underlies different principles when compared to natural rivers because of the highly limited and restricted river dynamic processes to which the targets of restoration, i.e., the rheophilic fish species characteristic for natural rivers, have evolutionary adapted to $[37,39]$.

Up to now, there is still a lack of scientific studies that compare the restoration effects in HMWBs, yet a critical evaluation of the usefulness of certain restoration measures alone or in concert, is urgently needed. Previous studies questioned the functionality of restoring instream habitats in HMWBs and concluded that they were not useful concerning a general improved population development over all size classes of species, such as C. nasus and B. barbus $[3,6]$. This leads to the question if there are other and more effective restoration or management measures that can contribute to an improvement of the 
population development of these highly specialised riverine fishes. To our knowledge, this is the first time that restoration measures inside the main channel, such as $\mathrm{BH}, \mathrm{JH}$, and $\mathrm{SH}$ have been compared with additional restoration measures outside, such as FP and SW.

In line with our initial hypothesis, none of the assessed habitats alone comprised the full set of species and/or size classes, indicating that only the interlinkage of the restored habitats can contribute to a successful self-sustainable fish population development and high biodiversity. While considering the two target species $C$. nasus and B. barbus, not all the assessed habitat types contributed equally to their population development. The separation between size classes distributed over different habitat types of these fish followed largely their distinct habitat requirements during different phases of their life cycle, i.e., spawning, juvenile growth, as well as specific habitats for feeding if these fish grow bigger. For example, slow-flowing and shallow water is crucial for the juvenile development, particularly of C. nasus and B. barbus $[11,40,41]$ and can be found mainly in SW and JH habitats after the restoration. Consequently, in these shallow habitats the highest proportion of small size classes of these fish were found in the whole study area. In contrast, larger (sub-adult) fish of these species $(11-30 \mathrm{~cm})$ preferred the habitats FP and SH where after implementation (FP) or restoration (SH) highest current speeds were recorded. Species, such as $C$. nasus, probably used these medium deep and light-exposed habitats for feeding on diatoms that grow on the coarse gravel on the river bottom, whilst B. barbus probably were feeding on higher trophic levels, such as macroinvertebrates for their part consuming primary producers on the ground. SH, FP, and SW probably can also function as spawning grounds for the target species since their abiotic habitat variables-particularly the low water depth with areas of less than $80 \mathrm{~cm}$ and the high current speed values-indicate sufficient spawning conditions after restoration $[15,16,40,42,43]$. In $\mathrm{JH}$, the expected small size of fish and many valuable small growing species, such as B. barbatula and G. gobio indicate that the restoration of structured shallow water zones with less current speed resulted in the intended effects. However, their location directly below the turbine outlet probably hindered better results for the target species. To reach these habitats, drifting larvae or juveniles have to pass the turbines of the power plants and to date it is not clear to which proportion these fish are injured or get killed there. This points to another important factor of restoring habitats in HMWBs, the location of were the restoration work is done. Since many larvae of the target species get passively drifted into habitats for their juvenile growth [40], it would be advantageous to place JH directly downstream of the spawning grounds. Since larvae drift can be very variable, this should be done in a sufficient number of replicates following the river course. In addition, the design of these habitats is crucial for their functionality [18]. JH should comprise a shallower bank angle to ensure escapement of the fish during high flows and the current speed should be reduced to provide finer substratum conditions. However, habitats $<1 \mathrm{~m}$ water depth are generally scarce in HMWBs, and therefore this approach is clearly an improvement of the former conditions. In light of this result, FP and SW can be considered important compensatory habitats in which many life-stage specific processes take place. In particular, in the SW that is managed with a dynamically changing discharge according to the runoff of the main river, channel forming processes, such as gravel relocation and dead wood dynamics, take place. These channel forming processes are the basis for creating and renewing important key habitats for all gravel dependent species, such as gravel-spawning fish or their food source diatoms or macroinvertebrates. C. nasus and B. barbus are both gravel spawners as well as salmonids, and are therefore highly dependent on oxygen-rich interstitial conditions for their early life stages egg and juvenile development [27].

In contrast to C. nasus and B. barbus, species less specialised and comprising a broad ecological amplitude, such as S. cephalus could develop well in BH. In addition, the habitats in the main channel comprise a distinctive set of valuable species preferring stagnant water conditions. These species can also be of high conservation value, e.g., the stagnophilic R. amarus that uses large freshwater mussels to lay its eggs in [43]. Since these species occurred in large numbers throughout the main channel of the Günz, they probably profit from a better connection of habitats through FPs and SWs, and a conflict of target species is not obvious between favouring rheophilic habitat conditions in restoration in the 
one hand and stagnophilic habitat requirements of these species on the other hand. Restored HMWBs can probably provide space likewise for fish with rheophilic, as well as for fish with stagnophilic life strategies.

\section{Conclusions}

River restoration, particularly in HMWBs, remains one of the unresolved challenges worldwide. In light of European policies, such as the WFD, there is still a growing demand to identify the most effective management options and restoration techniques for evidence-based sustainable restoration of structural deficits [44-46]. The findings of our study indicate that life stage requirements of highly specialised target species concerning their reproduction, juvenile growth or feeding habitats cannot solely be provided in deep slow flowing habitats of the main channel, but rather need a combination of different habitat restoration measures that are placed in appropriate local and interconnected arrangement. Furthermore, these results clearly indicate that restoring only bank habitats in HMWB-channels is not sufficient to restore the populations of highly specialised rheophilic target species. However, the habitats of the main channel can comprise besides valuable stagnophilic species a high number of non-specialised and ubiquitous species. Restoration in HMWBs should focus on both, the interlinkage of habitats comprising free fish migration and the life stage orientated morphological improvement of habitat structure and river dynamic processes to keep the structures renewing regularly. Fish migration in HMWBs should be restored while using nature like fish passes, since they comprise a large benefit as habitat for riverine fishes and river dynamic processes can be improved whenever old river courses below spillways can be used to absorb high discharges of the main channel.

Supplementary Materials: The following are available online at http:/ /www.mdpi.com/2073-4441/10/9/1202/ s1, Table Si1: Fish species detected in this study. $\mathrm{N}=$ number of individuals, $\mathrm{CP}=$ current preference (Zauner \& Eberstaller 1999 [35]), rh = rheophil, in = indifferent, st = stagnophil; RL BY = Red list Bavaria, Bohl et al. (2003 [47]); RL BRD = Red list Germany, Freyhof (2009 [48]), 2 = strong threatened, $3=$ threatened, $\mathrm{V}=$ species of concern.

Author Contributions: J.P. conceived and designed the experiments with support by J.G. J.P. performed the experiments, analysed the data, and together with J.G. conceived, structured and jointly wrote the paper.

Funding: This project has received funding from the Bayerische Elektrizitätswerke $\mathrm{GmbH}(\mathrm{BEW})$ for the habitat sampling. In addition, this project has received funding from European Union's Horizon 2020 research and innovation programme under grant agreement No 727830 for the data assessment.

Acknowledgments: We are grateful to F.J. Schick, the owner of the fishery rights at the Günz for his permission to carry out the study. We are also grateful to the Bayerische Elektrizitätswerke GmbH (BEW), in particular to R. Klocke for permission to carry out the investigation on their property. We also thank O. Born from "Fachberatung für Fischerei Schwaben" for the permission to carry out the electrofishing.

Conflicts of Interest: The authors declare, that they have no conflict of interest.

\section{References}

1. EU Commission. Towards Sustainable Water Management in the European Union. First Stage in the implementation of the Water Framework Directive 2000/60/EC; Commission staff Working Document. Accompanying Document to the Communication Forum from the Commission to the European Parliament and the Council COM 2007; EU Commission: Brussels, Belgium, 2007; p. 128.

2. Marchetti, M.P.; Moyle, P. Effects of flow regime on fish assemblages in a regulated California stream. Ecol. Appl. 2001, 11, 530-539. [CrossRef]

3. Pander, J.; Geist, J. Seasonal and spatial bank habitat use by fish in highly altered rivers-a comparison of four different restoration measures. Ecol. Freshw. Fish 2010, 19, 127-138. [CrossRef]

4. Pander, J.; Geist, J. Can fish habitat restoration for rheophilic species in highly modified rivers be sustainable in the long run? Ecol. Eng. 2016, 88, 28-38. [CrossRef]

5. European Parliament. Directive 2000/60/EC of the European Parliament and of the Council establishing a framework for the Community action in the field of water policy. Off. J. Eur. Union 2000, 327, 1-73. 
6. Pander, J.; Geist, J. Ecological indicators for measuring stream restoration success. Ecol. Indic. 2013, 30, 106-118. [CrossRef]

7. Boedeltje, G.; Smolders, A.J.P.; Roelofs, J.G.M.; Van Groenendael, J.M. Constructed shallow zones along navigation canals: Vegetation establishment and change in relation to environmental characteristics. Aquat. Conserv. Mar. Freshw. Ecosyst. 2001, 11, 453-471. [CrossRef]

8. Pulg, U.; Barlaup, B.T.; Sternecker, K.; Trepl, L.; Unfer, G. Restoration of spawning habitats of brown trout (Salmo trutta) in a regulated chalk stream. River Res. Appl. 2013, 29, 172-182. [CrossRef]

9. Tockner, K.; Schiemer, F.; Ward, J.V. Conservation by restoration: The management concept for a river-floodplain system on the Danube River in Austria. Aquat. Conserv. Mar. Freshw. Ecosyst. 1998, 8, 71-86. [CrossRef]

10. Pusey, B.J.; Arthington, A.H. Importance of the riparian zone to the conservation and management of freshwater fish: A review. Mar. Freshw. Res. 2003, 54, 1-16. [CrossRef]

11. Keckeis, H.; Winkler, G.; Flore, L.; Reckendorfer, W.; Schiemer, F. Spatial and seasonal characteristics of 0+ fish nursery habitats of nase, Chondrostoma nasus in the river Danube, Austria. Folia Zool. 1997, 46, 133-150.

12. Jurajda, P. Comparative nursery habitat use by $0+$ fish in a modified lowland river. Regul. Rivers Res. Manag. 1999, 15, 113-124. [CrossRef]

13. Schiemer, F.; Keckeis, H.; Kamler, E. The early life history stages of riverine fish: Ecophysiological and environmental bottelnecks. Comp. Biochem. Physiol. Part A 2003, 133, 439-449. [CrossRef]

14. Hauer, C.; Unfer, G.; Schmutz, S.; Habersack, H. Morphodynamic effects on the habitat of juvenile cyprinids (Chondrostoma nasus) in a restored Austrian lowland river. Environ. Manag. 2008, 42, 279-296. [CrossRef] [PubMed]

15. Melcher, A.H.; Schmutz, S. The importance of structural features for spawning habitat of nase Chondrostoma nasus (L.) and barbel Barbus barbus (L.) in a pre-Alpine river. River Syst. 2010, 19, 33-42. [CrossRef]

16. Britton, J.R.; Pegg, J. Ecology of European barbel Barbus barbus: Implications for river, fishery and conservation management. Rev. Fish. Sci. 2011, 19, 321-330. [CrossRef]

17. Jungwirth, M.; Muhar, S.; Schmutz, S. The effects of recreated instream and ecotone structures on the fish fauna of an epipotamal river. Hydrobiologia 1995, 303, 195-206. [CrossRef]

18. Pander, J.; Mueller, M.; Knott, J.; Egg, L.; Geist, J. Is it Worth the Money? The Functionality of Engineered Shallow Stream Banks as Habitat for Juvenile Fishes in Heavily Modified Water Bodies. River Res. Appl. 2017, 33, 63-72. [CrossRef]

19. Frissell, C.A.; Liss, W.J.; Warren, C.E.; Hurley, M.D. A Hierarchical Framework for Stream Habitat Classification: Viewing Streams in a Watershed Context. Environ. Manag. 1986, 10, 199-214. [CrossRef]

20. FAO/DVWK. FishPasses_Design, Dimensions and Monitoring; Food and Agriculture Organization of the United Nations, Deutscher Verband für Wasserwirtschaft und Kulturbau e.V.: Rome, Italy, 2002; p. 118.

21. Pander, J.; Mueller, M.; Geist, J. Ecological functions of fish bypass channels in streams: Migration corridor and habitat for rheophilic species. River Res. Appl. 2013, 29, 441-450. [CrossRef]

22. Arthington, A.H.; Bunn, S.E.; Poff, N.L.; Naiman, R.J. The challenge of providing environmental flow rules to sustain river ecosystems. Ecol. Appl. 2006, 16, 1311-1318. [CrossRef]

23. Poff, N.L.; Zimmerman, J.K. Ecological responses to altered flow regimes: A literature review to inform the science and management of environmental flows. Freshw. Biol. 2010, 55, 194-205. [CrossRef]

24. Beechie, T.J.; Sear, D.A.; Olden, J.D.; Pess, G.R.; Buffington, J.M.; Moir, H.; Roni, P.; Pollock, M.M. Process-based principles for restoring river ecosystems. BioScience 2010, 60, 209-222. [CrossRef]

25. Mueller, M.; Pander, J.; Geist, J. The ecological value of stream restoration measures: An evaluation on ecosystem and target species scales. Ecol. Eng. 2014, 62, 129-139. [CrossRef]

26. Kottelat, M.; Freyhof, J. Handbook of European Freshwater Fishes; Publications Kottelat: Cornol, Switzerland, 2007; p. 646.

27. Duerregger, A.; Pander, J.; Palt, M.; Mueller, M.; Nagel, C.; Geist, J. The importance of stream interstitial conditions for the early life stage development of the European nase (Chondrostoma nasus L.). Ecol. Freshw. Fish 2018. [CrossRef]

28. DWA 509. Merkblatt Deutsche Vereinigung für Wasserwirtschaft und Abfall e.V., Fischaufstiegsanlagen und Fischpassierbare Bauwerke—Gestaltung, Bemessung, Qualitätssicherung; Eigenverlag: Hennef, Germany, 2014; p. 284. 
29. Schneider, S.; Melzer, A. The trophic index of macrophytes (TIM) - A new tool for indicating the trophic state of running waters. Int. Rev. Hydrobiol. 2003, 88, 49-67. [CrossRef]

30. Gurnell, A.; Gregory, K.J.; Petts, G.E. The role of coarse woody debris in forest aquatic habitats: Implications for management. Aquat. Conserv. Mar. Freshw. Ecosyst. 1995, 5, 143-166. [CrossRef]

31. Gurnell, A.; Tockner, K.; Edwards, P.; Petts, G.E. Effects of deposited wood on biocomplexity of river corridors. Front. Ecol. Environ. 2005, 3, 377-382. [CrossRef]

32. Braun-Blanquet, J. Pflanzensoziologie: Grundzüge der Vegetationskunde; Springer-Verlag: Wien, Austria, 1964; p. 632.

33. Shannon, C.E.; Weaver, W. The Mathematical Theory of Communication; University of Illinois Press Urbana: Champaign, IL, USA, 1949; p. 117.

34. Pielou, E.C. The measurement of diversity in different types of biological collections. J. Theor. Biol. 1966, 13, 131-144. [CrossRef]

35. Zauner, G.; Eberstaller, J. Klassifizierungsschema der österreichischen Flußfischfauna in Bezug auf deren Lebensraumansprüche. Österreichs Fischerei 1999, 52, 198-205.

36. Dußling, U.; Bischoff, A.; Haberbosch, R.; Hoffmann, A.; Klinger, H.; Wolter, C.; Wysujack, K.; Berg, R. Der Fischregionsindex (FRI)—Ein Instrument zur Fließgewässerbewertung gemäß EG-Wasserrahmenrichtlinie. Wasserwirtschaft 2005, 95, 19-24.

37. Robinson, C.T.; Tockner, K.; Ward, J.V. The fauna of dynamic riverine landscapes. Freshw. Biol. 2002, 47, 661-677. [CrossRef]

38. Anderson, M.J.; Gorley, R.N.; Clarke, K.R. PERMANOVA+ for PRIMER: Guide to Software and Statistical Methods; PRIMER-E Ltd.: Plymouth, UK, 2008; p. 212.

39. Lytle, D.A.; Poff, N.L. Adaptation to natural flow regimes. Trends Ecol. Evol. 2004, 19, 94-100. [CrossRef] [PubMed]

40. Reinartz, R. Untersuchungen zur Gefährdungssituation der Fischart Nase (Chondrostoma nasus L.) in Bayerischen Gewässern; Technische Universität München, Institut für Tierwissenschaften-Dissertation: München, Germany, 1997; p. 241.

41. Ebel, G. Untersuchungen zur Stabilisierung von Barbenpopulationen-Dargestellt am Beispiel eines Mitteldeutschen Fließgewässers; Eigenverlag: Halle, Deutschland, 2002; p. 148.

42. Peňáz, M. Chondrostoma nasus-its reproduction strategy and possible reasons for a widely observed population decline-A review. In Conservation of Endangered Freshwater Fish in Europe; Birkhäuser: Basel, Switzerland, 1996; pp. 279-285.

43. Dávidová, M.; Blažek, R.; Trichkova, T.; Koutrakis, E.; Gaygusuz, Ö.; Ercan, E.; Ondračková, M. The role of the European bitterling (Rhodeus amarus, Cyprinidae) in parasite accumulation and transmission in riverine ecosystems. Aquat. Ecol. 2011, 45, 377-387. [CrossRef]

44. Hering, D.; Borja, A.; Carstensen, J.; Carvalho, L.; Elliott, M.; Feld, C.K.; Heiskanen, A.S.; Johnson, R.K.; Moe, J.; Pont, D.; et al. The European Water Framework Directive at the age of 10: A critical review of the achievements with recommendations for the future. Sci. Total Environ. 2010, 408, 4007-4019. [CrossRef] [PubMed]

45. Geist, J. Trends and Directions in Water Quality and Habitat Management in the Context of the European Water Framework Directive. Fisheries 2014, 39, 219-220. [CrossRef]

46. Geist, J. Seven steps towards improving freshwater conservation. Aquat. Conserv. Mar. Freshw. Ecosyst. 2015, 25, 447-453. [CrossRef]

47. Bohl, E.; Kleisinger, H.; Leuner, E. Rote Liste gefährdeter Fische (Pisces) und Rundmäuler (Cyclostomata) Bayerns; Bayrisches Landesamt für Umwelt: Augsburg, Germany, 2003; pp. 52-55.

48. Freyhof, J. Rote Liste der im Süßwasser reproduzierenden Neunaugen und Fische (Cyclostomata \& Pisces). Naturschutz und Biologische Vielfalt 2009, 70, 291-316.

(C) 2018 by the authors. Licensee MDPI, Basel, Switzerland. This article is an open access article distributed under the terms and conditions of the Creative Commons Attribution (CC BY) license (http:/ / creativecommons.org/licenses/by/4.0/). 